\title{
Effects of sublethal doses of beta-cyfluthrin on mutant Drosophila melanogaster (Diptera: Drosophilidae)
}

\author{
Gireesh Nadda ${ }^{\dagger}$, Prabhu N. Saxena* and Garima Srivastava \\ Toxicology Laboratory, Department of Zoology, School of Life Sciences, Khandari Campus, Dr. Bhim Rao Ambedkar University; \\ Agra, India 282002
}

(Received 22 April 2004; Accepted 15 December 2004)

\begin{abstract}
Laboratory experiment was conducted to examine sublethal effects of beta-cyfluthrin (Bulldock ${ }^{\circledR} 025 \mathrm{SC}$ ) on the sepia mutant of Drosophila melanogaster at a temperature of $25 \pm 0.5^{\circ} \mathrm{C}, 50 \pm 5 \%$ relative humidity and a photoperiod of $16: 8$ (light: dark) hours. Males and females were exposed separately to beta-cyfluthrin (one tenth of the calculated $\mathrm{LC}_{50}$ value) mixed in the diet for 24, 48 and $72 \mathrm{~h}$. Fecundity, hatchability, pupation, adult emergence, larval, pupal and total developmental periods were evaluated in the $F_{1}$ generation after various cross combinations. A reduction in fecundity, egg hatching, number of larvae, pupae, adults and prolongation of larval, pupal and total developmental periods was observed. A significant reduction $(p<0.05)$ in fecundity was observed only on the treated diet after treatment of both the sexes. Maximum effects were observed after $72 \mathrm{~h}$ treatment followed by 48 and $24 \mathrm{~h}$. Males were found to be more susceptible to beta-cyfluthrin as compared to the females.
\end{abstract}

Key words: Drosophila melanogaster; beta-cyfluthrin; sublethal; fecundity; developmental period

\section{INTRODUCTION}

Pyrethroid insecticides are often lethal to a wide variety of insect pests at extremely low doses (Khan, 1983), but at even lower doses these compounds have been shown to affect reproductive activities of several insect species (Haynes, 1988; Clark and Haynes, 1992). The effects of pesticides upon insects can be dramatic or quite subtle. Their applications at sublethal dosage were reported to cause resurgence problems, which can be due to physiological and/or ecological mechanisms (Luckey, 1968). Physiological resurgence (hormoligosis) of the brown planthopper, Nilaparvata lugens at low dosage of deltamethrin and methyl parathion was reported by Chelliah et al. (1980).

In assessing the effectiveness of an insecticide, the inclusion of effects on insects failing to acquire a lethal dose is often overlooked. The advantage of sublethal effects can supplement the lethal effects in many ways as by reducing the reproductive potential, inducing starvation, or causing the insects to avoid treated surfaces. Synthetic pyrethroids have been observed to exert such effects and have been reported to give better control and higher yields than expected from $\mathrm{LD}_{50}$ values (Armstrong and Bonner, 1985).

Insects including Drosophila, readily respond to toxins such as phytotoxins, metal ions and insecticides in their environment (Wilson, 2001). Hence, it becomes necessary to examine the possible effects to consider pesticide action causing direct mortality as well as that manifested through sublethal effects. Therefore, present study was undertaken to study sublethal effects of beta-cyfluthrin (Bulldock $^{\circledR} 025 \mathrm{SC}$ ) on the biology of $D$. melanogaster (Sepia mutant) in the $\mathrm{F}_{1}$ generation after various cross combinations of the parents that were exposed to sublethal concentration of insecticide, beta-cyfluthrin mixed in the diet for 24,48 and $72 \mathrm{~h}$.

\section{MATERIALS AND METHODS}

Collection and rearing of Drosophila melanogaster. Pure culture of sepia mutants of $D$.

\footnotetext{
* To whom correspondence should be addressed at: E-mail: dr_pnsaxena@yahoo.co.in

${ }^{\dagger}$ Present address: VPO-Soldha, District-Bilaspur, Himachal Pradesh, 174 032, India DOI: $10.1303 / \mathrm{aez} .2005 .265$
} 
melanogaster (Meigen) was obtained from Drosophila Stock Center, Indore, India. The culture was then reared on the artificial diet in glass culture bottles of $100 \mathrm{ml}$ capacity, at a temperature $25 \pm 0.5^{\circ} \mathrm{C}, 50 \pm 5 \%$ relative humidity and a photoperiod of $16: 8$ (light : dark) hours. Following ingredients were used for the preparation of diet: distilled water $360 \mathrm{ml}$, agar $2 \mathrm{~g}$, corn flour $17 \mathrm{~g}$, sugar $12 \mathrm{~g}$, yeast $3 \mathrm{~g}$, nepagin (methyl-4-hydroxybenzoate) $1 \mathrm{~g}$, propionic acid $1 \mathrm{ml}$ and $70 \%$ alcohol $1 \mathrm{ml}$.

Beta-cyfluthrin and $\mathbf{L C}_{\mathbf{5 0}}$ determination. Beta-cyfluthrin, $\mathrm{C}_{22} \mathrm{H}_{18} \mathrm{Cl}_{2} \mathrm{FNO}_{3}$ (Bulldock ${ }^{\circledR} 025$ $\mathrm{SC})$, a synthetic pyrethroid was obtained from Bayer India Limited, New Delhi, India. For the determination of $\mathrm{LC}_{50}$, mildly etherized 15 adult flies (3-5 h old) were selected randomly and exposed to serially diluted six different concentrations of the beta-cyfluthrin mixed in the diet. After $48 \mathrm{~h}$ of exposure, mortalities were recorded. Moribund flies were counted as dead. Collected data were analyzed by log-probit method (Finney, 1971). One tenth of the calculated $\mathrm{LC}_{50}$ value was selected as sublethal concentration for the treatment of flies.

Experimental protocol. To study the sublethal effects of beta-cyfluthrin, newly emerged (3-5 h old) males $(\delta)$ and females $(\$)$ were treated separately with one tenth of the calculated $\mathrm{LC}_{50}$ mixed in the diet, whereas control sets were given only equivalent amount of distilled water.

After 24,48 and $72 \mathrm{~h}$ of treatment, 10 males and 10 females drawn from the above sets were crossed as follows:

(i) The treated females ( $\mathrm{T}$ \%) were crossed with untreated males (UT $₫$ ) on untreated diet (UTD).

(ii) The treated males ( $\mathrm{T} \delta$ ) were crossed with untreated females (UT + ) on untreated diet (UTD).

(iii) The treated females ( $\mathrm{T}$ \%) were crossed with treated males (T $\hat{O})$ on untreated diet (UTD).

(iv) The treated females ( $\mathrm{T}$ \%) were crossed with treated males (T $\delta$ ) on the treated diet (TD) having insecticidal concentration equivalent to one tenth of calculated $\mathrm{LC}_{50}$ value.

For the control set, the untreated females (UT \%) were crossed with untreated males (UT $\left.{ }^{\star}\right)$ on untreated diet (UTD) having no insecticidal concentration but had equivalent amount of distilled water. The experiment was replicated thrice.
The treated sets and the control sets were kept at the preset conditions and after three days of mating adult flies were discarded and observations were recorded regularly on fecundity, egg hatching, pupation, adult emergence, larval period, pupal period, total developmental period. The eggs were collected (Delcour, 1969) and counted to determine the fecundity. Larvae that emerged from the eggs were counted to determine the hatchability. The time between the egg deposition and prepupation was taken as larval period. Pupation was considered to begin when anterior spiracles were everted and characteristically short, broad shape of the puparium was formed. Pupae were counted daily. Pupal period was recorded from prepupation to the emergence of adult. The emerged adults were anesthetized with anesthetic ether and counted. Total developmental period was calculated as the sum of larval and pupal periods.

Statistical calculations. The obtained data were analyzed statistically using Mann-Whitney $U$-test (SPSS, Release 7.5.1).

\section{RESULTS}

$\mathbf{L C}_{\mathbf{5 0}}$

$\mathrm{LC}_{50}$ of beta-cyfluthrin (Bulldock $\left.{ }^{\circledR} 025 \mathrm{SC}\right)$ after $48 \mathrm{~h}$ against $D$. melanogaster (Sepia mutants) was calculated as $0.73 \mu \mathrm{l} / 100 \mathrm{ml}$ diet $(y=2.2558 X-$ 1.5004, $R^{2}=0.98$ and fiducial limits; 0.746 and 0.713 ). The test insecticide produced a dose and time dependent toxicity and showed an antifeedant and repellent effects.

\section{Fecundity}

In the cross combinations, where either males, females or both the sexes were treated, the number of eggs laid by the females decreased (Tables 1, 2 and 3$)$. Fecundity decreased significantly $(p<0.05)$ in all the 24,48 and $72 \mathrm{~h}$ treatments on the treated diet and on the fresh diet only after $72 \mathrm{~h}$ treatment of both males and females, whereas, there was a non-significant $(p>0.05)$ reduction in all other treatment sets. Reduction in fecundity was greater after $72 \mathrm{~h}$ followed by 48 and $24 \mathrm{~h}$ treatment. However, the reduction is greater after the treatment of males as compared to females in all the treatment hours. 
Table 1. Sublethal effects of beta-cyfluthrin on Drosophila melanogaster (Sepia mutant) after $24 \mathrm{~h}$ treatment

\begin{tabular}{|c|c|c|c|c|c|c|c|}
\hline 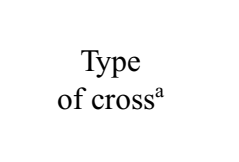 & $\begin{array}{l}\text { Fecundity } \\
(\text { No. })^{b} \\
\text { Mean } \pm \text { SE }\end{array}$ & $\begin{array}{l}\text { Hatchability } \\
\qquad \text { (No.) })^{\mathrm{b}} \\
\text { Mean } \pm \text { SE }\end{array}$ & 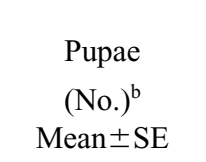 & $\begin{array}{c}\text { Adult } \\
\text { emergence } \\
{\text { (No. })^{\mathrm{b}}}^{\text {Mean } \pm \text { SE }}\end{array}$ & $\begin{array}{l}\text { Larval } \\
\text { period } \\
\text { (day) } \\
\text { Mean }\end{array}$ & $\begin{array}{c}\text { Pupal } \\
\text { period } \\
\text { (day) } \\
\text { Mean }\end{array}$ & $\begin{array}{c}\text { Total developmental } \\
\text { period (TDP) } \\
\text { (day) } \\
\text { Mean }\end{array}$ \\
\hline $\mathrm{T} q \times \mathrm{UT} \widehat{o}(\mathrm{UTD})$ & $147.7 \pm 13.9 a$ & $142.3 \pm 14.0 \mathrm{a}$ & $129.3 \pm 12.3 \mathrm{a}$ & $125.0 \pm 11.5 \mathrm{a}$ & 6.0 & 4.0 & 10.0 \\
\hline $\mathrm{UT} q \times \mathrm{T} o ̛(\mathrm{UTD})$ & $140.3 \pm 13.7 \mathrm{a}$ & $134.0 \pm 13.4 \mathrm{a}$ & $120.67 \pm 13.0 \mathrm{a}$ & $117.3 \pm 12.2 \mathrm{a}$ & 6.3 & 4.1 & 10.4 \\
\hline 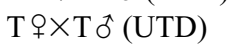 & $139.3 \pm 11.3 \mathrm{a}$ & $132.0 \pm 10.7 \mathrm{a}$ & $115.3 \pm 10.1 \mathrm{a}$ & $112.3 \pm 9.5 \mathrm{a}$ & 6.4 & 4.1 & 10.5 \\
\hline $\mathrm{T}+\mathrm{T}_{\mathrm{T}} \widehat{o}(\mathrm{TD})$ & $103.0 \pm 9.9 b$ & $91.0 \pm 8.7 \mathrm{~b}$ & $68.0 \pm 6.4 \mathrm{~b}$ & $66.3 \pm 6.1 \mathrm{~b}$ & 7.0 & 4.1 & 11.1 \\
\hline $\begin{array}{l}\mathrm{UT}+\times \mathrm{UT}^{-} \\
\text {(UTD, Control) }\end{array}$ & $151.7 \pm 14.1 \mathrm{a}$ & $148.3 \pm 14.1 \mathrm{a}$ & $139.3 \pm 12.6 \mathrm{a}$ & $136.3 \pm 12.5 \mathrm{a}$ & 6.0 & 4.0 & 10.0 \\
\hline
\end{tabular}

${ }^{\mathrm{a}} \mathrm{T}$, Treated; UT, untreated; TD, treated diet; UTD, untreated diet; 9 , female; $\widehat{0}$, male.

${ }^{\mathrm{b}}$ Means with the different letters within a column are significantly different when compared to control at the 5\% level using the Mann-Whitney $U$-test $(n=6)$.

Table 2. Sublethal effects of beta-cyfluthrin on Drosophila melanogaster (Sepia mutant) after $48 \mathrm{~h}$ treatment

\begin{tabular}{|c|c|c|c|c|c|c|c|}
\hline $\begin{array}{c}\text { Type } \\
\text { of cross }^{\mathrm{a}}\end{array}$ & $\begin{array}{l}\text { Fecundity } \\
(\text { No. })^{\mathrm{b}} \\
\text { Mean } \pm \text { SE }\end{array}$ & $\begin{array}{l}\text { Hatchability } \\
\qquad(\text { No. })^{\mathrm{b}} \\
\text { Mean } \pm \text { SE }\end{array}$ & $\begin{array}{c}\text { Pupae } \\
(\text { No. })^{b} \\
\text { Mean } \pm \text { SE }\end{array}$ & $\begin{array}{c}\text { Adult } \\
\text { emergence } \\
(\text { No. })^{b} \\
\text { Mean } \pm \text { SE }\end{array}$ & $\begin{array}{c}\text { Larval } \\
\text { period } \\
\text { (day) } \\
\text { Mean }\end{array}$ & $\begin{array}{l}\text { Pupal } \\
\text { period } \\
\text { (day) } \\
\text { Mean }\end{array}$ & $\begin{array}{c}\text { Total developmental } \\
\text { period (TDP) } \\
\text { (day) } \\
\text { Mean }\end{array}$ \\
\hline $\mathrm{T} q \times \mathrm{UT} \delta$ (UTD) & $146.0 \pm 15.3 \mathrm{a}$ & $139.3 \pm 15.0 \mathrm{a}$ & $126.0 \pm 13.6 \mathrm{a}$ & $122.7 \pm 13.5 \mathrm{a}$ & 6.1 & 4.1 & 10.2 \\
\hline UT $q \times \mathrm{T} \widehat{\text { (UTD) }}$ & $134.0 \pm 13.9 \mathrm{a}$ & $126.0 \pm 13.3 \mathrm{a}$ & $113.3 \pm 12.2 \mathrm{a}$ & $110.3 \pm 11.9 \mathrm{a}$ & 6.3 & 4.1 & 10.4 \\
\hline $\mathrm{T} q \times \mathrm{T} \widehat{o}(\mathrm{UTD})$ & $119.0 \pm 12.6 \mathrm{a}$ & $112.0 \pm 11.7 \mathrm{a}$ & $95.7 \pm 10.7 b$ & $93.3 \pm 10.1 \mathrm{~b}$ & 6.4 & 4.2 & 10.6 \\
\hline $\mathrm{T} q \times \mathrm{T} \widehat{\jmath}(\mathrm{TD})$ & $97.0 \pm 11.3 \mathrm{~b}$ & $85.3 \pm 10.4 b$ & $63.0 \pm 7.5 \mathrm{~b}$ & $61.7 \pm 7.2 \mathrm{~b}$ & 7.0 & 4.2 & 11.2 \\
\hline $\begin{array}{l}\mathrm{UT}+\times \mathrm{UT}^{-}{ }^{\circ} \\
\text { (UTD, Control) }\end{array}$ & $154.3 \pm 14.3 \mathrm{a}$ & $150.0 \pm 14.2 \mathrm{a}$ & $142.3 \pm 12.8 \mathrm{a}$ & $139.7 \pm 12.8 \mathrm{a}$ & 6.0 & 4.0 & 10.0 \\
\hline
\end{tabular}

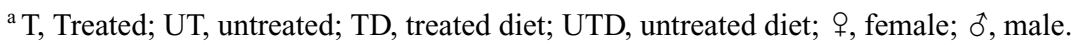

${ }^{\mathrm{b}}$ Means with the different letters within a column are significantly different when compared to control at the 5\% level using the Mann-Whitney $U$-test $(n=6)$.

Table 3. Sublethal effects of beta-cyfluthrin on Drosophila melanogaster (Sepia mutant) after $72 \mathrm{~h}$ treatment

\begin{tabular}{|c|c|c|c|c|c|c|c|}
\hline $\begin{array}{c}\text { Type } \\
\text { of cross }^{\mathrm{a}}\end{array}$ & $\begin{array}{l}\text { Fecundity } \\
(\text { No. })^{\mathrm{b}} \\
\text { Mean } \pm \text { SE }\end{array}$ & $\begin{array}{l}\text { Hatchability } \\
\qquad \text { No. })^{\mathrm{b}} \\
\text { Mean } \pm \text { SE }\end{array}$ & $\begin{array}{c}\text { Pupae } \\
{\text { (No. })^{\mathrm{b}}}^{\text {Mean } \pm \text { SE }}\end{array}$ & $\begin{array}{c}\text { Adult } \\
\text { emergence } \\
{\text { (No. })^{b}}_{\text {Mean } \pm \text { SE }}\end{array}$ & $\begin{array}{c}\text { Larval } \\
\text { period } \\
\text { (day) } \\
\text { Mean }\end{array}$ & $\begin{array}{c}\text { Pupal } \\
\text { period } \\
\text { (day) } \\
\text { Mean }\end{array}$ & $\begin{array}{c}\text { Total developmental } \\
\text { period (TDP) } \\
\text { (day) } \\
\text { Mean }\end{array}$ \\
\hline $\mathrm{T} q \times \mathrm{UT} o ̛(\mathrm{UTD})$ & $134.0 \pm 14.2 \mathrm{a}$ & $126.7 \pm 13.0 \mathrm{a}$ & $112.7 \pm 12.4 \mathrm{a}$ & $109.3 \pm 11.8 \mathrm{a}$ & 6.1 & 4.1 & 10.2 \\
\hline $\mathrm{UT} q \times \mathrm{T} o ̛(\mathrm{UTD})$ & $120.0 \pm 10.7 \mathrm{a}$ & $109.3 \pm 9.2 b$ & $96.0 \pm 8.1 \mathrm{~b}$ & $93.3 \pm 8.2 \mathrm{~b}$ & 6.3 & 4.1 & 10.5 \\
\hline $\mathrm{T} q \times \mathrm{T} o \hat{(U T D})$ & $110.7 \pm 10.2 b$ & $100.0 \pm 8.9 \mathrm{~b}$ & $82.7 \pm 7.9 b$ & $80.3 \pm 7.6 b$ & 6.5 & 4.2 & 10.6 \\
\hline $\mathrm{T} q \times \mathrm{T} \delta$ (TD) & $92.7 \pm 11.9 \mathrm{~b}$ & $80.0 \pm 10.1 \mathrm{~b}$ & $58.7 \pm 7.5 b$ & $57.3 \pm 7.8 \mathrm{~b}$ & 7.0 & 4.2 & 11.2 \\
\hline $\begin{array}{l}\mathrm{UT} q \times \mathrm{UT}^{-} \widehat{ } \\
\text { (UTD, Control) }\end{array}$ & $160.7 \pm 15.0 \mathrm{a}$ & $156.7 \pm 15.3 \mathrm{a}$ & $148.0 \pm 14.0 \mathrm{a}$ & $144.7 \pm 14.1 \mathrm{a}$ & 6.0 & 4.0 & 10.0 \\
\hline
\end{tabular}

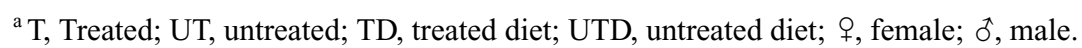

${ }^{\mathrm{b}}$ Means with the different letters within a column are significantly different when compared to control at the $5 \%$ level using the Mann-Whitney $U$-test $(n=6)$. 


\section{Hatchability}

A reduction in hatchability was observed in all the treatment sets as compared to the control. After male and female treatment reduction in the number of hatching was found to be significant after 24, 48 and $72 \mathrm{~h}(p<0.05)$ of treatment on the treated diet, whereas in the parallel cross, the decrease was significant $(p<0.05)$ on the fresh diet only after $72 \mathrm{~h}$ treatment. However, there was a significant reduction $(p<0.05)$ in fecundity after treatment of males for $72 \mathrm{~h}$. In all other cross combinations there was a non-significant reduction $(p>0.05)$. The decrease in egg hatching was relatively more after $72 \mathrm{~h}$ treatment followed by 48 and $24 \mathrm{~h}$. Thus, showing time dependent toxicity (Tables 1, 2 and 3). In all the exposure periods, the reduction in egg hatchability was found to be greater after male as compared to female treatment.

\section{Pupation and adult emergence}

The pupation and adult emergence decreased in all the crosses and exposure periods. Minimum effect was found after $24 \mathrm{~h}$ and maximum after $72 \mathrm{~h}$ of exposure. After treatment of females, a non-significant $(p>0.05)$ reduction in the number of pupae was observed in all the treatments (Tables 1,2 and $3)$. After treatment of males, pupation decreased significantly $(p<0.05)$ only in $72 \mathrm{~h}$ treatment. When both the sexes were treated and crossed on the fresh diet, the reduction was found to be significant after 48 and $72 \mathrm{~h}(p<0.05)$ treatments. Whereas, reduction was found to be significant $(p<0.05)$ in the parallel crosses but on the treated diet after 24, 48 and $72 \mathrm{~h}$ treatments.

The number of adults emerged decreased in all the crosses at all the treatment hours and reduction was found to be time dependent. Females were found to be resistant as compared to males. After treatment of females the reduction in the number of adults was found to be non significant $(p>0.05)$ in all the treatment hours, whereas it was significant $(p<0.05)$ only after $72 \mathrm{~h}$ treatment of the males. The number of adults emerged after male and female treatments was greater on the fresh diet as compared to the same cross but on the treated diet in all the three treatments. After treatment of both the sexes, the reduction was found to be significant on the fresh untreated diet after 48 and 72 $(p<0.05) \mathrm{h}$ exposures, whereas a significant reduction $(p<0.05)$ was observed on the treated diet in all the exposure periods (Tables 1, 2 and 3).

\section{Total developmental period}

Prolongation of total developmental (larval and pupal) period of $F_{1}$ generation was observed in all the crosses and maximum effects were observed after $72 \mathrm{~h}$ followed by 48 and $24 \mathrm{~h}$ treatment (Tables 1, 2 and 3). Maximum prolongation of larval, pupal and total developmental periods was observed on the treated food in the crosses where both the sexes were treated followed by the parallel crosses but on untreated diet. The increases in the total developmental on the treated diet after treatment of both the sexes were 10.99, 11.94 and $12.22 \%$ and on untreated fresh food 4.8, 6.12 and $6.41 \%$ over control after 24,48 and $72 \mathrm{~h}$ treatments, respectively. The increase in the developmental periods was greater after treatment of males $(3.6,4.62,4.91 \%)$ as compared to females $(0.60$, $1.71,2.00$ over control) after 24,48 and $72 \mathrm{~h}$ treatments, depicting that female were more resistant to beta-cyfluthrin as compared to males.

\section{DISCUSSION}

A sublethal dosage application of insecticides has often induced resurgence in insect pest populations (Ripper, 1956) that can be due to increased fecundity of females, i.e., physiological resurgence and/or hormoligosis (Luckey, 1968). However, no resurgence was found in the present study. Fecundity, hatchability, pupation and adult emergence were decreased, whereas, larval, pupal and total developmental period were prolonged as compared to the control. Maximum effects were observed after $72 \mathrm{~h}$ followed by 48 and $24 \mathrm{~h}$ treatment showing time dependent toxicity. Maximum effects were observed on treated diet after treatment of both sexes, followed by similar cross but on fresh untreated diet, and was attributed to the longer period of exposure of the adults as well as other developmental stages also to the sublethal concentration of the insecticide mixed in the diet. Direct contact of the immature stages to the insecticide resulted in its direct penetration and accumulation inside the body.

The sublethal effects on all the parameters studied were greater after treatment of males as compared to females. The apparent effect of the insecticide on the males and females at the same concen- 
tration may be due to their size difference. Males being smaller (Mean weight $=0.91 \pm 0.02 \mathrm{mg} /$ individual), receive a larger dose of insecticide than the females (Mean weight $=1.11 \pm 0.04 \mathrm{mg} /$ individual) in relation to body weight. Further, differential resistance to beta-cyfluthrin by different sexes of organisms may be attributed to the differential rate of detoxification in both the sexes. Females being larger contain more fat bodies, which kept the lipophilic toxicants away from the sensitive sites by storing a large amount of it, and thus, provide a sort of insulation against insecticides. In the present study, more susceptibility of males to betacyfluthrin as compared to females in all the exposure periods is in accordance to Clark and Haynes (1992) who reported similar results in cabbage looper, Trichoplusia ni. Dhingra et al. (1988) on the basis of $\mathrm{LD}_{50}$ values reported that females of $D$. melanogaster were more resistant $\left(\mathrm{LD}_{50}=\right.$ $1.40 \mathrm{ppm})$ to deltamethrin as compared to males $\left(\mathrm{LD}_{50}=0.8 \mathrm{ppm}\right)$.

Reduction in fecundity may be due to the inhibitory effect of beta-cyfluthrin on gonadial development. The inhibition of oviposition by a chemical may be caused by blocking the necessary endocrine secretion (Pratt et al., 1980), inhibition of ovarian development or malformation of ovipositing organs (Asai et al., 1985). A significant reduction $(p<0.05)$ in fecundity on the treated diet after both male and female treatment may be due to the exposure of parents for a longer duration including egg laying period also. Grafton-Cardwell and Hoy (1985) reported a significant reduction in the number of eggs laid by the females on the treated diet after treatment of Chrysoperla carnea with permethrin and fenvalerate for 24 and $48 \mathrm{~h}$. A reduction in fecundity of Spodoptera littoralis as a sublethal effect of pyrethroid insecticides was reported by Radwan et al. (1984). In the present study, disruption of mating or early separation may be one of the reasons for the reduction in ovulation due to improper insemination. Kwan and Gatehouse (1978) reported in Glossina morsitans that treated flies mated readily but early separation occurred more frequently in pairs including insecticide treated males, which may impede insemination and ovulation. The reduction in fecundity after female treatment may be due to the direct impact of betacyfluthrin on various tissues such as trophocytes, prefollicular tissue, follicular epithelium and oocyte themselves (Kaur et al., 1993) or hormonal imbalance. Chemical treatment affects the hormones, which subsequently disturb the nutritional pathway involving yolk deposition and release of neurosecretion is suspended, thereby inhibiting the vitellogenesis (Taneja et al., 1979).

In the present study, egg hatching decreased and the ovicidal action may be due to the accumulation of the insecticide in the eggs resulting in their direct death. The eggs which are laid but do not hatch, may be the result of inappropriate incorporation of the yolk so that the embryo failed to complete its developmental phases (Kaur et al., 1993). In addition to it, decrease in egg hatching may be due to antifeedant and repellant effects of betacyfluthrin, which resulted week and non-viable egg laying (Moore, 1980). Kumar and Chapman (1984) reported similar results after using permethrin, fenvalerate, methamidophos and carbaryl against Plutella xylostella. The observed reduction in egg hatching may be due to inability of the embryos to perforate the surrounding vitelline membrane, probably due to a weakened chitinous mouth hook assembly required for hatching (Wilson and Cryan, 1997). A decline in egg hatching was observed in Culex pipiens after exposure of adults to low dosages of alphacypermethrin by Zhang et al. (1990).

Larval development was affected in a time-dependent manner and high mortalities were observed during the larval stages in all the exposure periods. Maximum larval deaths observed during the first and second larval instars is in accordance to Laamanen et al. (1976) who observed similar results in D. melanogaster after using amitrol and reported that these mortalities may probably be due to specific ability of aminotrizole to inhibit the activity of catalase. The activity of catalase enzyme appears during the early larval stages of development. Beta-cyfluthrin perhaps also acted like amitrol to inhibit the activity of catalase. Present findings reveal that the later larval stages of $F_{1}$ generation were relatively unaffected when adults were fed with sublethal concentrations of insecticides. Greater mortality during larval stages may be due to the cytotoxic effects of the insecticide. Chowdhury et al. (2001) reported that chlorinated pesticides possess cytotoxic potential to $D$. melanogaster when administrated in the diet. In some cases, the eggs which hatched but died dur- 
ing moulting from one larval instar into other may probably be due to delayed obstruction of metabolic activities and can be the result of a defective gene expression causing abnormal genetic makeup of the egg (Kaur et al., 1993).

The pupation and adult emergence decreased in all the crosses and exposure periods. The deaths of prepupal and pupal stages were due to the latent toxicity of insecticide as reported by Kumar and Chapman (1984). The death during pupation or pupae may be because of less feeding by the larvae due to the antifeedant effect of beta-cyfluthrin, which resulted in inadequate food reserve in the developing pupae, as the pupae is a non-feeding stage. Further, test insecticide may have an adverse effect on the moulting. The reduction in the number of adults emerged can be attributed to the cumulative mortalities at various developmental stages.

Prolongation of larval, pupal and total developmental periods were observed in the entire cross combinations in all the treatment sets as compared to the control. The lengthening of developmental period may be due to some cytotoxic effects of beta-cyfluthrin or due to over production of juvenile hormone. On the treated diet, larval and pupal growth rate was reduced as a consequence of feeding inhibition. Beta-cyfluthrin might affect growth to cover metabolic costs associated with detoxification of the insecticide. A reduction in relative consumption rate (RCR) of diet due to knockdown and slight repulsive or antifeedant effects of betacyfluthrin has already been reported in S. litura in cyfluthrin-exposed larvae (Bernard and Lagadic, 1993). Laamanen et al. (1976) reported two days increase in the total developmental period of $D$. melanogaster after administration of amitrol in the diet.

From the present study, it is clear that betacyfluthrin even at sublethal concentrations affected the reproductive performance of $D$. melanogaster and did not induce hormoligosis. The response shown by sepia mutant flies after dietary exposure of adults for 24,48 and $72 \mathrm{~h}$ to sublethal concentrations of beta-cyfluthrin clearly indicated that the test insecticide showed dose and time dependent toxicity, had an antifeedant and repellent effects, was ovicidal in action, resulting in reduction of the number of eggs, larvae, pupae, adults in addition to the prolongation of the larval, pupal and total de- velopmental periods. The females were more resistant to beta-cyfluthrin as compared to males.

\section{ACKNOWLEDGEMENTS}

Authors are thankful to Dr. (Mrs.) Nishi Saxena for critical review of this manuscript. The help rendered by Mr. Ramji Lal during this research work is highly acknowledged.

\section{REFERENCES}

Armstrong, K. F. and A. B. Bonner (1985) Investigation of a permethrin-induced antifeedant effect in Drosophila melanogaster: an ethological approach. Pestic. Sci. 16: 641-650.

Asai, T., O. K. Kajihara, M. Fukada and S. Maekawa (1985) Studies on the mode of action of buprofezin II. Effects on reproduction of the brown planthopper, Nilaparvata lugens Stål (Homoptera: Delphacidae). Appl. Entomol. Zool. 20: 111-117.

Bernard, L. and L. Lagadic (1993) Sublethal effects of dietary cyfluthrin on nutritional performance and gut hydrolase activity in larvae of the Egyptian cotton leafworm, Spodoptera littoralis. Pestic. Biochem. Physiol. 46: 171-180.

Chelliah, S., L. T. Fabellar and E. A. Heinrichs (1980) Effect of sub-lethal doses of three insecticides on the reproductive rate of the brown planthopper, Nilaparvata lugens, on rice. Environ. Entomol. 9: 778-780.

Chowdhury, D. K., A. Nazir and D. K. Saxena (2001) Effect of three chlorinated pesticides on hsrw stress gene in transgenic Drosophila melanogaster. J. Biochem. Mol. Toxicol. 15: 173-186.

Clark, D. C. and K. F. Haynes (1992) Sublethal effects of cypermethrin on chemical communication, courtship, and oviposition in the cabbage looper (Lepidoptera: Noctuidae). J. Econ. Entomol. 85: 1771-1778.

Delcour, J. (1969) A rapid and efficient method of egg collecting. Drosophila Inf. Serv. 44: 133-134.

Dhingra, G., J. B. Chowdhury and P. K. Sareen (1988) Preliminary studies in Drosophila treated deltamethrin. Drosophila Inf. Serv. 67: 30-32.

Finney, D. J. (1971) Probit Analysis. Cambridge University Press, Cambridge, UK. 303 pp.

Grafton-Cardwell, E. E. and M. A. Hoy (1985) Short term effects of permethrin and fenvalerate on oviposition by Chrysoperla carnea (Neuroptera: Chrysopidae). J. Econ. Entomol. 78: 955-959.

Haynes, K. F. (1988) Sublethal effects of neurotoxic substances on the behavioral responses of insects. Annu. Rev. Entomol. 33: 149-168.

Kaur, H., R. Sandhu and S. S. Dhillon (1993) Substituted pyrimidine-2-thiols: A newly discovered group of antifertility agents against red cotton bug. Indian J. Ent. 55: 396-403.

Khan, N. Y. (1983) An assessment of the hazard of synthetic pyrethroid insecticides to fish and fish habitat. In Pesticide Chemistry: Human Welfare and the Environment (S. Maysunaka, D. H. Hutson and S. D. Murphy eds.). Vol. 3. Pergamon, New York, pp. 437-450. 
Kumar, K. and R. B. Chapman (1984) Sub lethal effects of insecticides on the diamondback moth Plutella xylostella (L.). Pestic. Sci. 15: 344-352.

Kwan, W. H. and A. G. Gatehouse (1978) The effects of low doses of three insecticides on activity, feeding, mating, reproductive performance and survival in Glossina morsitans morsitans (Glossinidae). Entomol. Exp. Appl. 23: 201-221.

Laamanen, I., M. Sorsa, D. Bamford, U. Gripenberg and T. Meretoja (1976) Mutagenicity and toxicity of amitrol. 1 Drosophila tests. Mutat. Res. 40: 185-190.

Luckey, T. D. (1968) Insecticide hormoligosis. J. Econ. Entomol. 61: 7-12.

Moore, R. F. (1980) Behavioural and biological effects of NRDC-161 as factors in control of the boll weevil. $J$. Econ. Entomol. 73: 265-267.

Pratt, G. E., R. C. Jeuning, A. H. Hammett and G. T. Brooks (1980) Lethal metabolism of precocene-1 to a reactive epoxide by locust corpora allata. Nature 284: 320-323.

Radwan, H. S. A., O. M. Assal and M. E. Samy (1984) Reproductive inhibition activity of certain synthetic pyrethroids and IGRs against the cotton leafworm, Spodoptera littoralis (Boisd.). Z. Angew. Entomol. 97: 130-133.

Ripper, W. E. (1956) Effect of pesticides on balance of arthropod populations. Annu. Rev. Entomol. 1: 403438.

Taneja, S. K., V. Sood, S. Taneja and A. Nath (1979) Effect of apholate on neurosecretion of pars intercerebralis, fat bodies and ovarian development of the red cotton bug, Dysdercus koenigii (F.). Indian J. Exp. Biol. 17: 133138.

Wilson, T. G. (2001) Resistance of Drosophila to toxins. Annu. Rev. Entomol. 46: 545-571.

Wilson, T. G. and J. R. Cryan (1997) Lufenuron, a chitinsynthesis inhibitor, interrupts development of Drosophila melanogaster. J. Exp. Zool. 278: 37-44.

Zhang, B. M., R. D. Xue, Y. F. Zeng, R. M. Xu and B. M. Lu (1990) Study of influence of Fendona on larval development and oviposition of Culex pipiens pallens. Chinese J. Parasitic Dis. Control. 3: 286-289. 